\title{
Collective Memory of International Women's Day in Part of the Feminist Community in Croatia
}

\section{Abstract}

The article examines the collective memory of International Women's Day in part of the feminist community in Croatia. Having in mind the importance of social context and mnemonic communities for the (re)construction of memory, the development of women's movements in Yugoslavia and Croatia is presented. Relying on Zerubavel's concept of collective memory and qualitative analysis of interviews, this paper discusses the origins of International Women's Day, its historical horizon, the memory of commemorations in socialist and post-socialist periods, and the mnemonic battles arising around them. Data necessary to describe these elements of collective memory of International Women's Day was collected through semi-structured interviews conducted with several members of the feminist community in Croatia. Even though today's feminist community in Croatia, to a certain point, consolidates the legacies of both bourgeois feminism and proletarian feminism, collective memory of International Women's Day, at least on the part of the feminist mnemonic community, serves as a reminder of its socialist or communist origins. An important form of commemoration in both the socialist and the post-socialist period is public commemoration, whether as protest walks or petition signings. On the other hand, commemorative pluralism and overall decline in the importance or symbolic value of IWD in Croatian society in the post-socialist period, is the most significant difference from the period of socialism. Elements of IWD which appear in both the socialist and post-socialist period and are the focal points of mnemonic battles that are fought over the meaning of IWD and its forms of commemoration are: Mother's Day and Valentine's Day symbolism, the conflict between politicized commemoration and depoliticized 
celebration, and cooptation or patronization by the politics. The most important factor for the appearance of mnemonic battles is found in the emergence of independent feminism, during the liberalization of Yugoslavian society in the seventies.

Keywords: International Women's Day, collective memory, feminist community

\section{Introduction}

International Women's Day in former Yugoslavia and Croatia had an interesting and rich past primarily due to the dynamic changes it endured over time. From its first commemoration it has seen its peak in the form of mass celebrations, then a suspension or temporary oblivion, and finally a renewed memory. At the time of mass celebrations it shared characteristics of both state holiday and some folk festivity. There has been little research on IWD, and none is concentrated primarily on the memory of the feminist community. Ethnologist Rihtman - Auguštin and anthropologist Sklevicky both deliberate the IWD from a perspective of the invention of tradition. On the other hand, historian Ida Ograjšek, while conceptually drawing from their work, analyzes newspaper articles in the period from 1946 until 1986 and concludes that social integration was the main function IWD performed in multiethnic Yugoslavia. Finally, Jovanka Kecman deals with IWD only casually, but provides an exhaustive overview of the women's involvement with the workers' movement and women's organizations in the period $1918-1941$.

Sklevicky places IWD within the socialist tradition and women's struggle to be included in workers' movements on an equal basis, calling it "women's socialist day" (172). In that regard, besides Klara Zetkin and the International Conference of Socialist Women, held in Kopenhagen in 1910, she also mentions the demonstration by New York women workers that is believed to have been held on March 8, 1857 (even though there are no data in American historical sources which would verify these claims), demonstrations by Chicago women workers held on March 8, 1901 and demonstrations by Russian women workers from 1913. The presence of the American tradition she explains with reference to French historian Kandel who claims that this is a consequence of workers' movement activists trying to separate IWD from the Soviet tradition in the Cold War 
period. At last, having in mind the activist aspect of feminism it is interesting to note her view of IWD as a convenient day for "launching new women's initiatives" (Sklevicky, 171).

For Rihtman - Auguštin IWD is more specifically a political ritual, which like invented tradition calls upon a past tradition to show continuity in its ever changing symbolic meaning. For her the flow of socialist holidays and rituals can be compared to that of an agrarian annual cycle, and IWD can be seen as an announcement of spring in the socialist calendar. She further reminds us of the tradition of a ritual gathering of women on Carnival Monday, so called revene, which was an inversion of gender roles and behaviof ${ }^{[1]}$. Also, she points to Weber - Kellermann's observation that this gender inversion during women's carnivals is only short-term. In that sense, Rihtman Auguštin interprets IWD as a modern form of women's gathering that leans against an already present folk tradition and that more often functions as a mechanism of social control than efficient political action or protest against existing gender inequality.

With regard to the symbolic meaning of commemoration, an interesting distinction between commemorating and celebrating, which was introduced by Sklevicky and Čolović (in Rihtman Auguštin, 126), should also be mentioned here. It was accepted later by researchers like Rihtman - Auguštin and Ograjšek, as well as by the feminists themselves, and points to the difference between commemorating as educational and propagandistic symbolism, and celebration as folk symbolism that has as a consequence the de-politicization of IWD.

\section{Goals and Methodology}

Grounded in a qualitative methodology and relying heavily on Zerubavel's theoretical conceptualization, the article presents collective memory of International Women's Day in part of the feminist community in Croatia. Having in mind the importance of social context and mnemonic communities (Zerubavel) for the (re)construction of memory, the characteristics of the women's movement in Yugoslavia and Croatia and its role and position in a wider socio-political context of socialist Yugoslavia and post-socialist Croatia are also discussed. The data necessary to describe the collective memory of International Women's Day in part of the feminist community in Croatia was collected within a period from March to August 2011 through semi-structured interviews on an intentional sample of six members of the Croatian feminist community. Precisely because of the 
small sample, which covered a limited segment of the feminist community, the respondents were chosen specifically among those members of the feminist community who are closer to positions of power, and therefore have the opportunity to influence public perception of feminism and the feminist movement in Croatia, as well as the developments in Croatian feminism itself. In other words, they are professors at university and/or activists in respectable NGOs. They present significant mediators of collective memory of IWD, in both Croatian society and the feminist (mnemonic) community itself. Interviews were recorded on tape and the structure of the interview can be found in the appendix.

Since social memory is a complex phenomenon that is at the same time subjective and objective, accurate and inaccurate, and in general selective, distorted and little affected by its truth (Fentress and Wickham), the emphasis is primarily on the content of collective memory. In other words, this perspective is not interested in the truthfulness of the content of memory. Impressions or accounts that might be or are in fact corroborated by historical data all have the same value. Hence, memories are not and are not intended to be treated as historical facts. In that sense it can be said that memory is always a conglomerate of impressions, truthful and untruthful memories, fantasies and historical facts, and all these mutually entangled elements coexist in memory.

\section{Theoretical Framework}

Zerubavel defines collective memory of a group as:

\section{[...] quite different from the sum total of the personal recollections of its various individual} members, as it includes only those that are commonly shared by all of them (...) It thus involves integration of various different personal pasts into a single common past that all members of a particular community come to remember collectively. (293-294)

Like Halbwachs, who was the first to introduce collective memory as a research subject and theoretical concept into sociology (in Misztal, 50), Zerubavel emphasizes the importance of the social environment in understanding memory. He sees changes in the content of memory as connected to the social changes that affect specific mnemonic communities situated in a wider society. For him the most important characteristic of collective memory is that most of it is not 
personally known to us, but is socially mediated through the work of mnemonic communities. This mediation includes interpretation and filtration of memories, which in the end lead to its distortion. Mnemonic communities, which enable sharing of memory, vary in forms - from nations, families, professional groups, religious groups and so forth. The initiation of an individual to the collective memory of a particular group happens during a process of mnemonic socialization, when a person gets acquainted with a certain mnemonic tradition and its specific normative conventions or rules of remembering that govern schematic structures which are narratives of the past or collective memory. Mnemonic tradition also includes the historical horizon or a specific time in the past that is considered to be the beginning of a certain narrative. At last, unlike Halbwachs' (in Misztal), Zerubavel's understanding of collective memory is dynamic. For him pluralism of collective memories or narratological pluralism often leads to disagreements over the right way to interpret the past. These disagreements or mnemonic battles, as he calls them, always manifest themselves in the public sphere.

\section{Development of Women's Movements in Yugoslavia and Croatia}

The feminist (mnemonic) community that is present today in Croatia is primarily rooted in independent feminism, which appeared in the seventies in Croatia and Yugoslavia. This independent feminism established itself on the foundations and in opposition to the two currents in the women's movement that preceded it. Emergence of the women's movement on this territory started at the end of the 19th and beginning of the 20th century, and was marked by rapid development of capitalism and civic society (Kecman, 5), pronounced traditionalism and existing patriarchal social environment. At the same time a process of women employment started, and it enabled women to leave the family circle (Kecman, 5) and redefine their traditional roles as mothers, wives or daughters. Women's education and struggle for the right to vote (Ograjšek Gorenjak, Kecman) were two other moments important for redefining traditional understanding of femininity.

Thus, at the turn of the century, both women's civic organizations or bourgeois feminism, and women workers' organizations or proletarian feminism, started to appea ${ }^{[2]}$. At the time, the firmly 
traditional and patriarchal social environment had a restrictive effect on both of them. The substantial lack of political, social and economic power of women, made these two movements dependent on the support from the top. While women's civic organizations were depending on the support from the Church and Court $(162,168)$, women workers' organizations depended on the support from the worker's movement or the Communist Party of Yugoslavia (Kecman, 13-15, 69). Women's civic organizations existed till WW2 and their membership consisted of intellectuals and well-off women who were concerned with humanitarian work and advocated the women's right to vote and education for women $(6-11,168-70,189-90)$, but even though they argued for men and women's equality, unlike women workers' organizations they mostly did not consider it necessary for women to join political parties or form their own (Kecman, 186, 193-94). Due to their respect for the political order and insistence on political neutrality (Kecman, 169, 266), they were often marked as reactionary and even accused of collaboration with the fascist government (Sklevicky, 80, note 64). Evidence of mutual cooperation between these organizations and women workers' organizations, which grew stronger with the ascent of fascism (Kecman, 185, 289-91, 333-35), led some authors (i.e. Skelvicky, Feldman) to discard these accusations as completely unjustified.

Primary interests of women workers' organizations were women's work rights and women's right to vote, but they also functioned as very important agitators for the Communist (Socialist) movement and ideology among women (Kecman, 87-93, 125-44, 197-03). According to the Statute of the unified women's Socialist (Communist) movement this organization fully adopted the program of the Communist Party and was considered to be the executive committee for agitation and organization of women (Kecman, 78). The Statute of the Anti-fascist Front of Women shows that this organization was fully incorporated in the People's Front (129), while following the Fifth Congress of the Communist Party of Yugoslavia it is designated as a recruitment center for the Communist Party (Sklevicky, 131). The AFW was established in 1942 (82) and was the most important women's organization during the Second World War and in the post war period - until the fifties when it was first de-professionalized (138), then dissolved and substituted by Conferences for social activity of women . It activated women to participate in the People's Liberation War (38) and gave great attention to the education of women, believing that the literacy of women and general education constitute the basis for further political education and inclusion of 
women in the Communist Party of Yugoslavia (Sklevicky, 30-31). It is important to note that despite all this, the majority of activities of the AFW led to the reaffirmation of the traditional role of women in society (Sklevicky, 39, 121-22, 137).

Due to the patriarchal surroundings, both currents of the women's movement constrained themselves in redefining the role and status of women, and adjusted their rhetoric to the worldview of those on whose support they depended. The progressive parts of the bourgeoisie accepted the idea of the education of women only if it stayed in accordance with the women's role as caretakers and therefore conveyers of the national spirit (Ograjšek-Gorenjak, 162, 167-68, 175) and the women's right to vote was advocated pointing to a benefit it might have for the nation (Boban, 20203). On the other hand, the progressive parts of the working class accepted the idea of women's political activation and emancipation in general only to the extent that it serves as an instrument of the socialist revolution (Sklevicky, 57,108 ), and only if it remained completely controlled by the superior political workers' organization ${ }^{3]}$. In both cases the demands for changes in the status and role of women in the society were never justified by its intrinsic value for women, but by the value these changes might have for the nation or the revolutionary class. The rejection of such an understanding of emancipation occurred with the emergence of independent feminism.

Independent feminism, which first occurred at the university, was a repercussion of neo-feminist development, liberalization of Yugoslavian society and the weakening of totalitarian institutions during the seventies that created a sociopolitical climate which favored social and political criticism (Knežević, 249). The reaction of the Communist party and its women's organization to the public debates organized by these groups, where they questioned the assumed gender equality in socialist Yugoslavia - that was promoted by the proletarian feminism - and discussed patriarchal and conservative aspects of Yugoslavian society, was to criticize the ideas of independent feminists and to accuse them of falling into bourgeois ideology (Knežević, 249-52). While the eighties were characterized by pronounced activism and cooperation of many feminist groups and initiatives that were formed in Zagreb, Ljubljana and Beograd, the disintegration of Yugoslavia in the nineties led to the disintegration of the Yugoslavian feminist scene and polarization of the Croatian feminist scene, between the groups that accept the new nationalistic ideology and rhetoric, and those that defy it (Knežević, 254-56). New feminist groups continued to emerge 
during the nineties, and since then their activism has included street actions directed towards such issues as violence against women, abortion rights, inequality between men and women in the sphere of politics and work, as well as the "systematization (and also production) of knowledge as the basis for various types of women's and gender studies" (Knežević, 258). It can be said that the seventies and eighties were the period when the conceptual and organizational framework, and the conditions for ongoing and later feminist activities in Croatia, were established. The emergence of women's groups whose activities were independent from the Communist Party of Yugoslavia, and who inclined toward a critical thinking of government, presented a sort of precursor to the civil society. Or at least, they presented groups which, after the disintegration of Yugoslavia and the establishment of a pluralist society, because of their former activist experience, were able to continue their activities inside the growing sphere of civil society.

\section{Collective Memory of International Women's Day in part of the feminist community in Croatia}

Following the structure of the interview and Zerubavel's concept of collective memory, the analysis of the interviews revolves around several themes: origins of IWD and its historical horizon, the memory of the socialist and post-socialist period which includes forms of commemoration, and mnemonic battles. The analysis showed that the origins of IWD are found in the women's struggle for social equality that includes the right to vote and women workers' rights. There exists a tendency towards a specific foundation of IWD in the International Socialist (Communist) movement. This is clearly revealed in the respondents' mentioning of specific women's workers demonstrations in Chicago and New York. Likewise, they see the origins of IWD to be the result of the Second International and activism of Klara Zetkin. Based on the statements of respondents we can conclude that, on the one hand, IWD is seen as a consequence of a formal decision that was made during the Second International, when the International Conference of Socialist Women was held and Klara Zetkin suggested that women should gather once a year to demand the right to vote ${ }^{[4]}$. On the other hand, IWD is seen as commemorating specific demonstrations. In the latter case, the women workers' demonstrations are believed to be the events which preceded and conditioned the formal inauguration of IWD within the Second International. Therefore, it can be observed that 
despite the fact that respondents see IWD as an event which commemorates the women's struggle for social equality, women's right to vote and women workers' rights, the origins of this holiday are entirely associated with women workers' organizations and the workers' movement as a whole, that is the Communist movement, and not with women's civic organizations. However, among the respondents there is the idea of pre-war commemorations of IWD in Croatia and Yugoslavia due to the existence of the local socialist movement. They place the historical horizon or the beginning of commemoration and the narrative of IWD in the WW2 period and associate it with the activities of the AFW. Furthermore, they suppose pre-war commemorations existed, but they could not say anything specific about them. In other words, occasional commemorations that have been held since 1914 (Kecman) are banished into obscurity and are present in the collective memory in a more implicit than explicit manner.

With regard to the socialist period, the respondents explicitly stated that IWD started to resemble Mother's Day or that it turned into Mother's Day. They remember cards and small gifts that were given to mothers. Also, the respondents remember flower bouquets or in particular red carnations that were given to women at work or at home, the loss of revolutionary spirit and the prevailing commercialization manifested in other kinds of mandatory gifts, excursions organized by firms or syndicates, a day off given by the State and the State's patronization of IWD, as well as the mass celebration of IWD which ceased to be the site of political discussion about women's status in society but became the site of entertainment and festivity. Overall, the memory is dominated with a sense of dissatisfaction which is expressed by respondents saying that they disliked, or were disgusted by this, or that it made them angry. It can be concluded that just as giving gifts to mothers evokes Mother's Day symbolism, which the respondents explicitly stated, celebrating women by lavishing them with gifts, flowers, or affection in general, suggests also a presence of Valentine's Day symbolism in IWD. The combination of the state patronizing IWD, and lack of political discussion about women's status in society or loss of the revolutionary spirit, commercialization and mass festivity, resulted in de-politicization of IWD. Furthermore, it produced yet another interesting characteristic: large groups of women in a public space. The respondents distinctly remember large groups of women on the streets, in bars, and on excursions organized by firms or syndicates. This reported increase in the public visibility of women seemingly points to the 
socio-political power of women in socialist Yugoslavia. However, since these gatherings were completely devoid of any political content and served solely for entertainment, it can be concluded that these festive mass gatherings of women, which were made possible by a day off given to women by the regime, in fact symbolized the socio-political and economic power of the state or the Communist Party of Yugoslavia.

As the eighties were a period of flowering activism, autonomous feminist groups started to organize a separate public commemoration. They sought to re-politicize IWD and therefore to make the woman's question or woman's issue a relevant political issue again expanding its existing legal and economic content with the problematization of sex/gender relations in the private sphere. Respondents said that during that period IWD became an occasion to discuss violence against women and mention the return of the commemorations to the street or in the squares where they would commemorate IWD by organizing petition signing or activities like the 1988 commemoration in Zagreb that included putting up the first SOS Hotline for Women and Children Victims of Violence in the whole of Yugoslavia. Therefore, it can be noticed that one of the main methods for re-politicizing IWD was to return the commemorations into a public space where activists and other women who joined them became visible socio-political subjects, independently choosing and presenting themes they felt are important to women at a specific moment.

The beginning of the nineties brought about the disintegration of Yugoslavia in the form of war and the suppression of the memory of IWD. The respondents hold that the initial disappearance or suppression of IWD was the consequence of a change in the political regime, accompanied by strong nationalist sentiments and conservative values, which suppressed all socialist ideas, iconography and holidays, anything that bore the memory of the previous regime. Also, they remember turning to humanitarian activities at the time, establishing the Center for Women Victims of War and helping conscientious objectors (men who refused to serve in the military), and due to all this putting IWD commemorations aside. It can be noticed that, on the one hand, the disappearance of IWD was the result of the feminist community putting aside IWD, and on the other, the suppression of the memory of IWD, that was celebrated across Yugoslavia and often served as a promotion tool for the Communist party. Also, besides national exclusivity, the new government advocates a return to traditional notions of femininity (Rihtman - Auguštin, 133) which 
are not compatible with the idea of women's rights that IWD presumably promoted, despite the fact that during socialism it had already started losing its political content to a more traditional presentation of femininity.

Relatively soon, in time while there is still a nationalist conservative government in power, IWD started to reappear. Feminist organizations started to regularly commemorate IWD in the midnineties, while the broader society begins to accept it with the beginning of the new millennium. The respondents consider that the main reasons for its comeback are the ending of immediate war activities which made possible for feminist groups to once again redirect and also broaden their activities, and the establishment of new feminist groups and organizations, like the Women's Network of Croatia, which apart from readdressing the issues of the political and economic situation of Croatian women, worked on returning the IWD commemorations to the public space. Also, they perceive outside influences, especially from Europe, that allowed for better receptivity of leftist ideas and the coming of the left coalition to power in 2000 to be the most important factors that influenced a renewed acceptance of IWD in wider society.

Thus, the focus of the state on pro-European politics, the change of government in 2000 , and the engagement of feminist groups in maintaining the memory of IWD, contributed to its gradual renormalization. The main difference in relation to the socialist period can be found in commemorative pluralism. Respondents notice that beside feminist groups, IWD is being separately commemorated by the government and individual political parties. They report that on occasions they are asked to give a speech at commemorations held on the premises of political parties. They also notice that IWD is present in the mass-media who regularly inform the public about the commemorations. Based on the statements of respondents, two types of commemorative behavior can be distinguished within the feminist community. Private commemoration takes the form of personal congratulations to women for their significant achievements. Public commemorations take place on the street and/or city squares, but also in semi-public areas like the premises of civic organizations, political parties or a theater. Public commemorations that take place on the streets include protest processions with banners, which point to specific political demands. Processions head toward symbols of political power towards which the demands are primarily directed, like the House of Parliament. It can be said that, while 
semi-public commemorations are reminiscent of the former gala ceremonies organized by the Communist Party for IWD (Rihtman - Auguštin, Ograjšek), street commemorations have a strong activist note. It's not always about starting a new women's initiative as Sklevicky envisioned and as was the case with the opening of the SOS Hotline for Women and Children Victims of Violence in 1988, but rather the fact that IWD is the one day of the year that allows for greater visibility of issues of gender inequalities in public and is hence used to draw attention to some current issues concerning the status of women in Croatian society. The two other characteristics of IWD in the post-socialist period that were stated by the respondents are the decline in symbolic value and the absence of mass celebrations. It can be inferred that both of these characteristics stem from the loss of state sponsorship, which, in turn, is a consequence of the transition to a pluralist society. Therefore, despite the return of feminists' commemorations and a renewed acceptance of IWD in wider society, or the re-normalization of IWD, the overall impression is that IWD lost the importance it had in the post-socialist period.

In the end I would like to briefly address mnemonic battles that are fought over the meaning of IWD and its forms of commemoration. Besides being a specific issue of the politics of memory of IWD, these mnemonic battles also represent a certain continuity in the memory of IWD and are present in both the socialist and the post-socialist period. It can be noticed that even though these specific elements of IWD are reappearing in the post-socialist period, they are largely suppressed. The first one concerns the interference of Mother's Day and Valentine's Day symbolism in IWD. On its return into wider society, IWD again accommodated elements of MD and VD symbolism to which feminists are opposed. This is not that unusual if we bear in mind that the same overlap existed in the period of socialism and that the conservative part of the Croatian society leans towards traditional notions of women and femininity. The respondents remember that after the disintegration of Yugoslavia, IWD was replaced by Mother's Day and Valentine's Day due to the fact that previously it contained the characteristics of both. Some reasoned that on its return, an attempt was made to convert it into Mother's Day, while others noticed a slight tendency towards its commercialization. The second battle concerns the right way to commemorate IWD. Feminists insist that it should be a politicized commemoration and it seems that the wider society, and some politicians, would prefer a depoliticized and commercialized celebration. Accordingly, there is a 
tendency of losing the content that relates to the socio-political status and role of women in society, and the return of Mother's Day and Valentine's Day elements that are indicated by giving congratulations and flowers to women, or a variety of other gifts. The last battle concerns the relationship of the feminist community and the political system or the cooptation by the mainstream politics. In Yugoslavia IWD was co-opted by the Communist party. In the post-socialist period there are attempts of cooptation by political parties or certain politicians who try to exploit feminist groups and IWD for their own promotion. The most striking example carved into the memory of the respondents is associated with the mayor of Zagreb who turned up at a commemoration organized by the feminists on the main city square and overtook the commemoration by handing out flowers to people passing by and women who prior to that had gathered around a group of feminists activists commemorating IWD.

\section{Conclusion}

As the heir of independent feminism, today's feminist community in Croatia consolidates to a certain point the legacies of both bourgeois feminism and proletarian feminism. Still, at least for the part of the feminist mnemonic community today, IWD is a reminder that the origins of this community are to be found in proletarian feminism, or more specifically, the Communist movement. The historical horizon or the beginning of commemorations is considered to be the Second World War. The collective memory of the socialist period is characterized by the presence of Mother's Day and Valentine's Day symbolism, mass celebrations and the state's patronization of IWD, as well as the commercialization and overall de-politicization of IWD. In accordance with the mode of action of feminist groups, important forms of commemoration in both the socialist and post-socialist period were public commemorations, whether as protest walks or petition signings. This type of commemoration, which re-politicizes the meaning of IWD and provides a visibility of socio-political activities of feminists, stands in stark contrast with mass celebrations sponsored by the state in the period of socialism, and personal or private form of commemoration in the post-socialist period. The most significant difference between the period of socialism and post-socialism is found in commemorative pluralism and overall decline in the importance or symbolic value of IWD in Croatian society after the fall of Yugoslavia. Since the emergence of independent feminism and its 
commemorations of IWD, separate from state sponsored activities, the period of socialism was marked by commemorative dualism.

However, certain elements of IWD appear in the socialist and post-socialist period alike. These elements, often interlinked, present the focal points of mnemonic battles that are fought over the meaning of IWD and its forms of commemoration. These are: Mother's Day and Valentine's Day symbolism, the conflict between politicized commemoration and depoliticized celebration, and cooptation or patronization by mainstream politics. Since changes in the content of collective memory and its forms of commemoration are linked to socio-political changes that affect the mnemonic community which is situated in a wider society, hence the mnemonic battles are closely linked to the emergence and activities of independent feminism. Therefore, with the emergence of independent feminism as a precursor of civil society, it can be said that hints of pluralism can be found in the socialist period. Likewise, the appearance of commercialization and de-politicization of IWD during the socialist period happened at a time of weakening of totalitarian institutions and the liberalization of socialist society. As respondents themselves noticed, the initial disappearance of IWD in the post-socialist period, which happened with the disintegration of Yugoslavia, was a consequence of conservative, nationalist and antisocialist sentiments or ideology that emerged after the change of the political regime, and of feminist groups redirecting their work to humanitarian and antiwar activities and therefore putting IWD commemorations aside. In the same way, the return of IWD commemorations or the renormalization of IWD is a result of outside influences that allowed for better receptivity of leftist ideas, the leftist coalition coming to power and the return of feminist activism connected to IWD. In respect of the renewed incorporation of Mother's Day and Valentine's Day symbolism in IWD, it can be asserted that this is a consequence of the process of retraditionalization that appeared in Croatian society after the collapse of Yugoslavia, expressed by the government's promotion of the return to traditional notions of femininity (Rihtman - Auguštin). Furthermore, this renewed incorporation of Mother's Day and Valentine's Day symbolism can be ascribed to the fact that in the period of socialism IWD included both of these symbolisms. This notion is present in the interviews both implicitly and explicitly. 


\section{Appendix}

Interview - formal structure

1. Why is International Women's Day being commemorated?

2. Why is it being commemorated on March 8th?

3. Do you commemorate IWD, and if yes - how?

4. What would you say, when did IWD started being commemorated on Croatian territory?

5. In the beginning, what did those commemorations look like, who organized them and for whom?

6. What do you think, why did IWD started being commemorated on the territory of Croatia?

\section{Works Cited}

Boban, Branka. "“Materinsko carstvo" - zalaganje Stjepana Radića za žensko pravo glasa i ravnopravan položaj u društvu." Žene u Hrvatskoj: Ženska i kulturna povijest. Ed. Andrea Feldman. Zagreb: Ženska infoteka, 2004: 191-209. Print.

Feldman, Andrea. "Proričući gladnu godinu - žene i ideologija jugoslavenstva (1918. - 1939.)."

Žene u Hrvatskoj: Ženska i kulturna povijest. Ed. Feldman. Andrea. Zagreb: Ženska infoteka, 2004. 235-46. Print.

Fentress, James and Wickham, Chris. Social Memory. Oxford: Blackwell, 1992. Print.

Kaplan, Temma. On the Socialist Origins of International Women's Day. Feminist studies 11.1. (1985): 163-171. Print.

Kecman, Jovanka. Žene Jugoslavije u radničkom pokretu i ženskim organizacijama 1918 - 1941. Beograd: Narodna knjiga - Institut za suvremenu istoriju, 1978. Print. 
Knežević, Đurđa. "Kraj ili novi početak? - Feminizam od šezdesetih do danas u Jugoslaviji/Hrvatskoj." Žene u Hrvatskoj: Ženska i kulturna povijest. Ed. Feldman, Andrea. Zagreb: Ženska infoteka, 2004. 247-60. Print.

Misztal, Barbara. Theories of Social Remembering. London: Open University Press, 2003. Print. Ograjšek-Gorenjak, Ida. "“On uči, ona pogađa, on se sjeća, ona prorokuje” - pitanje obrazovanja žena u sjevernoj Hrvatskoj krajem 19. st." Žene u Hrvatskoj: Ženska i kulturna povijest. Ed.

Feldman, Andrea. Zagreb: Ženska infoteka, 2004. 157-79. Print.

Ograjšek, Ida. Osmi mart - Međunarodni dan žena. Povijest u nastavi 1.3. (2004): 112-141. Print.

Rihtman-Auguštin, Dunja. Ulice moga grada. Beograd: Biblioteka XX vek, 2000. Print.

Sklevicky, Lydia. Konji, žene, ratovi. Zagreb: Druga, 1996. Print.

Zerubavel, Eviatar. "Social Memories: Steps to a Sociology of the Past." Qualitative Sociology 19.3. (1996):283-300. Print. 
[1] This tradition which Malešević recorded in villages of Vojvodina and from which men were completely excluded, included a lot of food, drinks, music, and unbridled behavior of about twenty women and was held until the Second World War when it gave way to International Women's Day due to party officials objections to their merger (in Rihtman - Auguštin, 130).

[2] Sklevicky considers the period of $1942-1943$ to be the period of autonomy of the AFW (86).

Bourgeois feminism, proletarian feminism and independent feminism are technical terms used in literature on feminism in Yugoslavia and Croatia (Kecman, Sklevicky, Rihtman - Auguštin). Bourgeois feminism would be analogous to liberal feminism and the suffrage movement, while proletarian feminism is a combination of what is known as Marxist and socialist feminism. Even though independent feminism or neo-feminism is often called just feminism, I use the term independent feminism primarily because these organizations were autonomous and were not in any way related to the women's organizations of the Communist Party of Yugoslavia.

[3]

[4] According to Kaplan during the conference a specific date on which these gatherings should take place was not specified (166).

\section{(c) (i) (9)}

Creative Commons Attribution-NonCommercial-NoDerivatives 4.0 International License 